\title{
Feeding extruded linseed to dairy ewes under extensive grazing conditions
}

\author{
Einar Vargas-Bello-Pérez, Raúl R. Vera, Claudio Aguilar, Rodrigo Lira, \\ Iván Peña, and Franco. A. Tello \\ Facultad de Agronomía e Ingeniería Forestal, Pontificia Universidad Católica de Chile. Casilla-306, \\ Santiago, Chile.
}

\begin{abstract}
E. Vargas-Bello-Pérez, R. R. Vera, C. Aguilar, R. Lira, I. Peña, and F.A. Tello. 2014. Feeding extruded linseed to dairy ewes under extensive grazing conditions. Cien. Inv. Agr. 41(1): 115-122. The aim of this trial was to evaluate the effect of dietary supplementation of extruded linseed on the milk and cheese fatty acid (FA) profiles of ewes under extensive grazing conditions. Over 26 days, a group of nine lactating ewes (Latxa $\times$ Milchschaf $\times$ Corriedale) in mid-lactation were managed under grazing conditions and given supplements during each manual milking ( 0830 and $1800 \mathrm{~h})$ of $50 \%$ corn and $50 \%$ oats $\left(500 \mathrm{~g} \mathrm{ewe}^{-1}\right.$ milking ${ }^{-1}$; control, TC) for the first 6 days. From day 7 to 20, the supplement was $25 \%$ corn, $25 \%$ oats and $50 \%$ extruded linseed (500 $\mathrm{g} \mathrm{ewe}^{-1}$ milking ${ }^{-1}$ ) (extruded linseed; TEL). From day 21 to 26 , the ewes were fed TC. The saturated FA content in milk was reduced (3.6\%), and the monounsaturated, polyunsaturated and n-3 FA (7, 10 and 25\%, respectively) were increased when the ewes were supplemented with extruded linseed. A correlation between rumenic acid with vaccenic acid $\left(\mathrm{R}^{2}=0.68\right)$ was found in the milk fat from ewes fed TEL. In cheese obtained from TEL, the contents of n-3 and polyunsaturated FA were increased (21 and 7\%, respectively). In conclusion, a supplement of extruded linseed in ewes under grazing conditions could be an alternative lipid source to produce cheese with additional nutritional value. However, the effect of extruded linseed supplementation in ewes under the same conditions with longer experimental periods and a more suitable statistical design must be investigated.
\end{abstract}

Key words: Extruded linseed, n-3 fatty acids, cheese, ewe, milk.

\section{Introduction}

In recent decades, the potential positive health effects (anti-carcinogenic, anti-atherogenic and anti-obesity) of certain milk fatty acids (FA) such as n-3 FA and conjugated linoleic acid (CLA; C18:2 c9, t11) that are observed in dairy products have stimulated an interest in improving milk FA (Vargas-Bello-Pérez

Received July 5, 2013. Accepted March 20, 2014.

Corresponding author: evargasb@uc.cl and Garnsworthy, 2013). Because oilseeds are rich in C18:3n-3 and C18:2n-6, their inclusion in ruminant diets can increase the concentrations of specific health-promoting FA such as C18:3n-3 and C18:2 c9, t11 in milk (Manso et al., 2011). Ewe milk fat is an important natural source of CLA (approximately $1 \%$ of total FA; Luna et al., 2005), and rumenic acid (RA; $\mathrm{C} 18: 2 \mathrm{c} 9, \mathrm{t} 11)$ is the main CLA isomer, and it comprises almost $90 \%$ of the total CLA in ruminant milk fat (Zhang et al., 2006). 
Different studies have reported the effects of whole linseed (Luna et al., 2005), linseed oil (Bouattour et al., 2006) and extruded linseed (Gomez-Cortes et al., 2009; Mele et al., 2007, 2011; Mughetti et al., 2012; Branciari et al., 2012) on milk FA composition in ewes. However, few studies have investigated ewes that are supplemented with extruded linseed under extensive grazing conditions. The present trial was conducted to enhance ewes' milk fat by dietary means (extruded linseed) in a short time period. Furthermore, research on this topic could lead to the development of natural, consumerfriendly strategies and processing systems to produce CLA/n-3 enriched dairy foods with enhanced nutritional properties. Therefore, a 26-d trial was conducted to evaluate the effect of dietary supplementation of extruded linseed on the milk and cheese FA profile of ewes under extensive grazing conditions.

\section{Materials and methods}

\section{Animals and treatments}

The trial was performed from December 2010 to January 2011 in Ancud, Chile (42 ${ }^{\circ}$ '6" S $73^{\circ} 50^{\prime} 7$ " W). Over 26 days, a group of nine lactating multiparous ewes $(n=9)(50 \%$ Latxa $\times$ $25 \%$ Milchschaf $\times 25 \%$ Corriedale) with $90 \mathrm{~d}$ of lactation at the onset of the trial were managed under grazing conditions and supplemented during each manual milking (0830 and $1800 \mathrm{~h}$ ) with $50 \%$ corn and $50 \%$ oats $\left(500 \mathrm{~g} \mathrm{~g}^{-1}\right.$ milking $\left.^{-1}\right)$ (the control was the usual supplement, denoted TC) during the first 6 days; from day 7 to 20 , the supplement was based on $25 \%$ corn, $25 \%$ oats and $50 \%$ extruded linseed $\left(500 \mathrm{~g} \mathrm{ewe}^{-1}\right.$ milking ${ }^{-1}$ ) (extruded linseed; TEL), and from day 21 to 26, the ewes were fed TC. There was no adaptation period, and ewes were separated from their lambs before the trial. Ewes were allocated to a grazing paddock $\left(7000 \mathrm{~m}^{2}\right)$ with free access to water.
Measurements, sample collection and chemical analyses

Milk samples $(300 \mathrm{~mL})$ from each of the nine ewes were collected daily from the first milking $(0830 \mathrm{~h}$ ) in aliquots of $100 \mathrm{~mL}$ (preserved with $100 \mathrm{mg}$ of $\mathrm{K}_{2} \mathrm{Cr}_{2} \mathrm{O}_{7}$ ) and stored at $-20^{\circ} \mathrm{C}$ for later analysis. The supplements were sampled every two days and stored at $-20{ }^{\circ} \mathrm{C}$ for later chemical analysis. The standard procedures described by the Association of Official Analytical Chemists (AOAC, 2006) were used to determine the Kjeldahl $\mathrm{N}$ (984.13) and ether extract (920.39). The crude protein was calculated as $\mathrm{N} \times 6.25$, and the neutral detergent fiber was determined according to the methods described by Van Soest et al. (1991). Milk samples were analyzed for $\mathrm{pH}$, titratable acidity (Thörner degrees; Th), fat content (Gerber method; British Standards Institution 696, 1969), crude protein (16.036; Kjeldahl $\mathrm{N} \times 6.38$ ), total ash (16.035) and solids (16.032) according to the AOAC (1984) procedures.

\section{Grassland species characterization}

At the beginning of the trial, a line-intercept method (Sutherland, 2006) with transect lines was used to measure the cover and characterize the grassland species. Cover was estimated by measuring the length of the transect line occupied by each species and expressing it as a percentage of the total length. Each transect was 2-m length with 10-cm interval points, and they were distributed in random locations within the experimental paddock.

\section{Cheese-making process}

Cheese was produced from 4 consecutive milking times ( 2 from $0800 \mathrm{~h}$ and 2 from $1800 \mathrm{~h}$ ) over 2 days in which $10 \mathrm{~L}$ of raw milk was heated to 32 ${ }^{\circ} \mathrm{C}$ (at a rate of $1{ }^{\circ} \mathrm{C} 3 \mathrm{~min}^{-1}$ ), and a commercial rennet was added to curdle the milk at $38^{\circ} \mathrm{C}$. No 
starter culture was added to produce the cheese because raw milk was used. After the milk had clotted (40 min), the curd was cut to the size of a hazelnut and the vat temperature was gradually increased to $37{ }^{\circ} \mathrm{C}$ at a rate of $1^{\circ} \mathrm{C} 3 \mathrm{~min}^{-1}$. At the same time, the curd was stirred to remove the whey and favor grain aggregation. Curds were placed into molds $(16 \mathrm{~cm}$ diameter and 10 $\mathrm{cm}$ height) and pressed in a horizontal mechanic press until the $\mathrm{pH}$ was approximately 7.2. The cheese was salted in brine at $12{ }^{\circ} \mathrm{C}$ for $15 \mathrm{~h}$ and then transferred to a ripening room where it remained at a temperature of $12{ }^{\circ} \mathrm{C}$ and $\sim 85 \% \mathrm{RH}$ for $120 \mathrm{~d}$; afterwards, two cores of each cheese were obtained for FA analysis.

\section{Fatty acid analysis}

The analyses of the fatty acid methyl esters (FAME) from the experimental diets, extruded linseed, milk and cheese samples were performed using a gas chromatograph (GC; Shimadzu Scientific Instruments AOC-20s, Columbia, MD, USA) equipped with a $100 \mathrm{~m} \times 0.32 \mathrm{~mm} \times 0.20$ $\mu \mathrm{m}$ column (Rtx-2560). The lipid extraction / methylation and the GC conditions were similar to those reported by Vargas-Bello-Pérez et al. (2013). The fatty acid peaks were identified by using the Food Industry 37 FAME Mix (Restek Co, Bellefonte, PA, USA).

The nature of this trial and limited availability of on-farm facilities led to a "before and after" sequence of treatments applied to the whole group of experimental animals. A quasi-experimental design was used that included baseline data (first 6 and last 6 days of the trial) to measure the outcome before the intervention (lipid supplementation) and follow-up data to determine the outcome after a passage of time that was deemed sufficient (14 d) for the impact of the intervention to set in. The animal performance traits and chemical parameters of the milk and cheese were subjected to a one-way ANOVA analysis to compare the effects of the control and experimental diets using the
SAS Statistical Package (2004, SAS Inst. Inc., Cary, NC.). A probability of $\mathrm{P}<0.05$ was used to determine significant differences among means.

\section{Results and discussion}

The chemical composition of the dietary treatments is reported in Table 1. As expected, the most predominant FAs found in the extruded linseed were C18:2n-6 (17.3 g $\left.100 \mathrm{~g}^{-1}\right)$ and C18:3n-3 (51.9 $\left.\mathrm{g} 100 \mathrm{~g}^{-1}\right)$. The main species found in the experimental paddock (which represented $85 \%$ of the total grassland species coverage) were Agrostis tenuis, Trifolium repens and Anthoxanthum odoratum, whereas Lotus uliginosus contributed only $2 \%$. The remaining grassland species found in the paddock were identified as Dichondra repens, Juncus bufonius, Taraxacum officinale and Ranunculus repens.

Table 1. Chemical composition of dietary treatments (DM basis).

\begin{tabular}{lccc}
\hline $\begin{array}{l}\text { Chemical composition } \\
\left(\mathrm{g} \mathrm{kg}^{-1}\right)\end{array}$ & $\begin{array}{c}\text { Extruded } \\
\text { Control }^{1}\end{array}$ & $\begin{array}{c}\text { Extruded } \\
\text { linseed }\end{array}$ \\
\hline Crude fiber & 89 & 122 & 155 \\
Ether extract & 46 & 116 & 187 \\
Crude protein & 91 & 179 & 266 \\
Neutral detergent fiber & 236 & 232 & 229 \\
Ash & 19 & 31 & 44 \\
\hline
\end{tabular}

${ }^{1} 50 \%$ corn $+50 \%$ oats $\left(1000\right.$ g ewe $\left.^{-1} \mathrm{~d}^{-1}\right) ;{ }^{2} 25 \%$ corn $+25 \%$ oats $+50 \%$ extruded linseed $\left(1000 \mathrm{~g} \mathrm{ewe}^{-1} \mathrm{~d}^{-1}\right)$.

The milk yield was not affected by the inclusion of extruded linseed; however, the total solids, milk fat and $\mathrm{pH}$ were increased by TEL (Table 2). Luna et al. (2005) reported that there was no difference in milk yield and a decreased milk fat content when ewes were fed with a supplement enriched in whole linseed. In addition, no differences in milk fat content were reported by Gomez-Cortés et al. (2009) when ewes were fed extruded linseed (12\% DM). Usually, the dietary lipids in ruminant rations contributed significantly to the energy density of the diet, which is reflected in an increased milk yield (Akraim et al., 2006). The supplementation of TEL affected some of the physical characteristics of milk, and despite 
the increase in milk $\mathrm{pH}$, this value is within the physiological range reported for sheep milk (Park et al., 2007). The titratable acidity, a quality indicator of raw milk, was reduced, which suggested a lower content of molecules with buffering capacity, such as the casein fractions (Bianchi et al., 2004).

Table 2 Milk yield and milk composition of ewes receiving a diet supplemented with extruded linseed.

\begin{tabular}{|c|c|c|c|}
\hline Item & Control $^{1}$ & $\begin{array}{l}\text { Extruded } \\
\text { linseed }^{2}\end{array}$ & $P$-value ${ }^{3}$ \\
\hline Milk yield, $\mathrm{kg} \mathrm{d}^{-1,4}$ & $12.07 \pm 0.41$ & $12.19 \pm 0.30$ & 0.051 \\
\hline \multicolumn{4}{|l|}{ Milk composition, \% } \\
\hline Total solids & $18.54^{\mathrm{b}} \pm 0.16$ & $18.95^{\mathrm{a}} \pm 0.08$ & 0.028 \\
\hline Protein & $4.02 \pm 0.10$ & $3.98 \pm 0.02$ & 0.249 \\
\hline Fat & $6.82^{b} \pm 0.33$ & $7.18^{\mathrm{a}} \pm 0.07$ & 0.009 \\
\hline Ash & $1.01 \pm 0.01$ & $1.00 \pm 0.01$ & 0.539 \\
\hline Titratable acidity, ${ }^{\circ} \mathrm{Th}$ & $13.40^{\mathrm{a}} \pm 0.33$ & $12.00^{\mathrm{b}} \pm 0.20$ & 0.001 \\
\hline $\mathrm{pH}$ & $6.47^{b} \pm 0.02$ & $6.56^{\mathrm{a}} \pm 0.03$ & 0.017 \\
\hline \multicolumn{4}{|c|}{$\begin{array}{l}150 \% \text { corn }+50 \% \text { oats }\left(1000 \mathrm{~g} \mathrm{ewe}^{-1} \mathrm{~d}^{-1}\right) ;{ }^{2} 25 \% \text { corn }+25 \% \text { oats } \\
+50 \% \text { extruded linseed }\left(1000 \mathrm{~g} \mathrm{ewe}^{-1} \mathrm{~d}^{-1}\right) .{ }^{3} \mathrm{P} \text {-value represents } \\
\text { the probability of a treatment effect. }{ }^{4} \mathrm{Milk} \text { yield from } 2 \text { milking } \\
\text { times from } 9 \text { ewes. }{ }^{\mathrm{a}, \mathrm{b}} \mathrm{Means} \text { in the same row with different } \\
\text { superscripts are different }(\mathrm{P} \leq 0.05) \text {. }\end{array}$} \\
\hline
\end{tabular}

\section{Milk and cheese fatty acid composition}

The inclusion of TEL reduced the milk C16:0 and increased the C18:1 t11. Compared to TC, TEL increased the C18:2 t9, t11 and C18:3n-3 (Table 3). In this trial, increases in C18:2 isomers and C18:1 t11 contents in milk are most likely a result of the extensive hydrolysis and biohydrogenation occurring in the rumen. Two of the biohydrogenation intermediates that escape from the rumen are C18:1 t11 (vaccenic acid; VA), which is formed from both C18:2n-6 and C18:3n-3; and RA, which is formed during the biohydrogenation of linoleic acid (Vargas-Bello-Pérez and Garnsworthy, 2013) that is supplied by extruded linseed.

In this trial, the inclusion of extruded linseed reduced the milk saturated fatty acids (SFA) by $3.6 \%$. Mele et al. (2007) reported a 9.6\% decreased in milk SFA content when grazing ewes were supplemented with 30\% DM extruded linseed. Additionally, Gomez-Cortés et al. (2009) reported an $18 \%$ reduction of milk SFA when ewes were fed with extruded linseed. The fatty acids from C6:0 to C14:0 are synthesized de novo in the mammary gland, whereas $\mathrm{C} 16: 0$ is derived from both the diet and de novo synthesis. A substantial part of the reduction in de novo synthesis of FA as a result of feeding PUFA (e.g., extruded linseed) could be as a result of an increased uptake of dietary and ruminally derived FA (Vargas-Bello-Pérez and Garnsworthy, 2013).

The inclusion of TEL increased the amount of C18:2 t9, t11 and C18:3n-3 in the produced cheese (Table 3). The content of C18:3n-3, an intermediate product of the rumen biohydrogenation, was higher in TEL milk and cheese, which suggested that feeding extruded linseed to dairy ewes resulted in the ruminal accumulation of this FA, which may partly escape from the rumen and be transferred to milk and cheese (Plourde et al., 2007). Mele et al. (2011) also reported increases in cheese C18:3n-3 when ewes were fed a concentrate with $30 \%$ extruded linseed.

The saturated FA and thrombogenic index were decreased, and the monounsaturated FA, polyunsaturated FA, and polyunsaturated n-3 and n-6 FA were increased in milk. However, only the polyunsaturated FA and polyunsaturated n-3 and n- 6 FA were increased in cheese of ewes supplemented with TEL (Table 3). Although, the atherogenicity and thrombogenic indexes of the cheese were not affected by TEL, the atherogenicity index was lower (1.9 vs. 2.9) than that reported by Abilleira et al. (2009), who evaluated the effect of season of the year on the changes in management system of the commercial sheep flocks in the FA profile of Idiazabal cheese (a type of cheese similar to those elaborated in this trial). Furthermore, the data reported in Table 3 shows that throughout the trial, the atherogenicity index of the control diet tended to increase significantly $(\mathrm{P} \leq 0.05)$, whereas the diet of TEL showed a significant decreasing trend $(\mathrm{P} \leq 0.05)$. It should be noted that the FA composition of the local forage species and the effect of season on their lipid composition have not been determined 
Table 3. Fatty acid composition in milk and cheese from ewes receiving a diet supplemented with extruded linseed.

\begin{tabular}{|c|c|c|c|}
\hline Fatty acid $\left({\left.\mathrm{g} 100 \mathrm{~g}^{-1}\right)}\right.$ & Control $^{1}$ & Extruded linseed ${ }^{2}$ & $P$-value ${ }^{3}$ \\
\hline \multicolumn{4}{|l|}{ Milk } \\
\hline $\mathrm{C} 12: 0$ & $3.77 \pm 0.11$ & $3.54 \pm 0.12$ & 0.188 \\
\hline C14:0 & $11.52 \pm 0.32$ & $11.16 \pm 0.22$ & 0.357 \\
\hline C16:0 & $26.16 \mathrm{a} \pm 0.55$ & $24.69 \mathrm{~b} \pm 0.19$ & 0.021 \\
\hline C18:0 & $13.83 \pm 0.61$ & $14.58 \pm 0.31$ & 0.277 \\
\hline $\mathrm{C} 18: 1 \mathrm{t} 11$ & $5.41 \mathrm{~b} \pm 0.11$ & $6.00 \mathrm{a} \pm 0.11$ & 0.004 \\
\hline C18:1 c9 & $18.58 \pm 0.50$ & $18.28 \pm 0.39$ & 0.638 \\
\hline $\mathrm{C} 18: 2 \mathrm{c} 9, \mathrm{t} 11$ & $2.35 \pm 0.08$ & $2.44 \pm 0.08$ & 0.476 \\
\hline $\mathrm{C} 18: 2 \mathrm{n}-6$ & $1.43 \pm 0.02$ & $1.45 \pm 0.03$ & 0.552 \\
\hline C18:3n-3 & $0.95 \mathrm{~b} \pm 0.06$ & $1.19 \mathrm{a} \pm 0.05$ & 0.007 \\
\hline Saturated fatty acids & $68.55 \mathrm{a} \pm 0.72$ & $66.05 \mathrm{~b} \pm 0.60$ & 0.021 \\
\hline Monounsaturated (MUFA) & $26.95 \mathrm{~b} \pm 0.66$ & $28.81 \mathrm{a} \pm 0.54$ & 0.049 \\
\hline Polyunsaturated (PUFA) & $5.24 \mathrm{~b} \pm 0.09$ & $5.77 \mathrm{a} \pm 0.06$ & $<0.001$ \\
\hline PUFA n-3/n-6 & $2.09 \pm 0.12$ & $1.82 \pm 0.06$ & 0.066 \\
\hline Atherogenicity index ${ }^{4}$ & $2.37 \pm 0.11$ & $2.11 \pm 0.06$ & 0.055 \\
\hline Thrombogenic index ${ }^{5}$ & $2.91 \mathrm{a} \pm 0.09$ & $2.58 \mathrm{~b} \pm 0.04$ & 0.003 \\
\hline \multicolumn{4}{|l|}{ Cheese } \\
\hline C10:0 & $4.86 \pm 0.27$ & $4.87 \pm 0.16$ & 0.971 \\
\hline $\mathrm{C} 12: 0$ & $3.4 \pm 0.12$ & $3.22 \pm 0.09$ & 0.259 \\
\hline $\mathrm{C} 14: 0$ & $10.56 \pm 0.43$ & $10.58 \pm 0.12$ & 0.969 \\
\hline $\mathrm{C} 16: 0$ & $25.17 \pm 0.60$ & $24.41 \pm 0.16$ & 0.217 \\
\hline C18:0 & $14.69 \pm 0.58$ & $14.89 \pm 0.22$ & 0.744 \\
\hline $\mathrm{C} 18: 1 \mathrm{t} 11$ & $5.82 \pm 0.16$ & $6.15 \pm 0.11$ & 0.111 \\
\hline $\mathrm{C} 18: 1 \mathrm{c} 9$ & $19.52 \pm 0.59$ & $19.06 \pm 0.28$ & 0.476 \\
\hline $\mathrm{C} 18: 2 \mathrm{c} 9, \mathrm{t} 11$ & $2.59 \pm 0.05$ & $2.59 \pm 0.07$ & 0.946 \\
\hline C18:2n-6 & $1.48 \pm 0.01$ & $1.50 \pm 0.02$ & 0.626 \\
\hline C18:3n-3 & $0.96 \mathrm{~b} \pm .0 .05$ & $1.16 \mathrm{a} \pm 0.05$ & 0.013 \\
\hline Saturated fatty acids & $65.31 \pm 0.72$ & $63.99 \pm 0.45$ & 0.138 \\
\hline Monounsaturated (MUFA) & $29.14 \pm 0.66$ & $30.06 \pm 0.37$ & 0.233 \\
\hline Polyunsaturated (PUFA) & $5.58 \mathrm{~b} \pm 0.09$ & $5.96 \mathrm{a} \pm 0.11$ & 0.027 \\
\hline PUFA n-3/n-6 & $2.14 \pm 0.25$ & $1.91 \pm 0.14$ & 0.069 \\
\hline Atherogenicity index ${ }^{4}$ & $2.03 \pm 0.26$ & $1.94 \pm 0.09$ & 0.426 \\
\hline Thrombogenic index ${ }^{5}$ & $2.66 \pm 0.21$ & $2.48 \pm 0.09$ & 0.060 \\
\hline
\end{tabular}

${ }^{1} 50 \%$ corn $+50 \%$ oats $\left(1000 \mathrm{~g} \mathrm{ewe}^{-1} \mathrm{~d}^{-1}\right) ;{ }^{2} 25 \%$ corn $+25 \%$ oats $+50 \%$ extruded linseed $(1000 \mathrm{~g}$ ewe $\left.\mathrm{e}^{-1} \mathrm{~d}^{-1}\right) \cdot{ }^{3} \mathrm{P}$-value represents the probability of a treatment effect. ${ }^{4}$ Atherogenicity index $=[(12: 0+$ $4(14: 0)+16: 0] /[(\mathrm{n} 6+\mathrm{n} 3) \mathrm{PUFA}+18: 1+\Sigma$ MUFA $]\left(U l b r i c h t\right.$ and Southgate, 1991); ${ }^{5}$ Thrombogenic index $=(14: 0+16: 0+18: 0) /[(0.5 \times 18: 1)+0.5(\Sigma$ MUFA $)+0.5($ n6PUFA $)+3(n 3 P U F A)+(n 3 P U F A /$ n6PUFA)] (Ulbricht and Southgate, 1991). ${ }^{\mathrm{a}, \mathrm{b}}$ Means in the same row with different superscripts are different $(\mathrm{P} \leq 0.05)$. 
to date. Plant species and season have been shown to markedly influence the FA composition, and these variations are reflected in the sheep milk fat composition (Mel'uchova et al., 2008).

Rumenic acid (C18:2 c9, t11) and vaccenic acid (C18:1 t11) relationship

Throughout the 26-d trial, the milk FA profile was altered by TEL. Figure 1 shows the temporal patterns that occurred in C18:0, C18:1 t11, C18:2 c9, t11 and C18:3n-3 when ewes were fed extruded linseed. In this trial, the temporal patterns of milk were similar to those reported by Luna et al. (2005) in which an increase in C18:2 c9, t11 in milk of ewes supplemented with whole linseed (17\% DM) was observed; however, they reported an increase in C18:0 and C18:3n-3, whereas in this trial, the concentrations of $\mathrm{C} 18: 0$ remained constant with a slight tendency to be reduced and $\mathrm{C} 18: 3 \mathrm{n}-3$ was increased within the first days post supplementation with TEL and then reduced after the $10^{\text {th }}$ day.

The rumenic acid content in milk fat was not affected by TEL. In this trial, a significant correlation of rumenic acid with vaccenic acid $(\mathrm{Y}=0.6002 \mathrm{x}$ $-1.089, \mathrm{R}^{2}=0.6854$ ) was found in milk fat from ewes fed TEL. This correlation value was lower than the value reported by Nudda et al. (2005), Luna et al. $(2005,2008)$ and Gomez-Cortes et al. (2009) $\left(\mathrm{R}^{2}=0.97,0.94,0.98\right.$ and 0.87 , respectively). There are several factors that may intervene in these differences, such as the number of animals used in this trial versus the larger flocks used by Luna et al. $(2005,2008)$ and Nudda et al. (2005).

High levels of dietary lipids often induce timedependent ruminal adaptations that lead to alterations in the formation of specific biohydrogenation intermediates (e.g., C18:2 c9, t11) (Vargas-Bello-Pérez and Garnsworthy, 2013). In our trial, ewes were supplemented extruded linseed for 14 days, whereas the other studies used longer periods of time (Gomez-Cortes
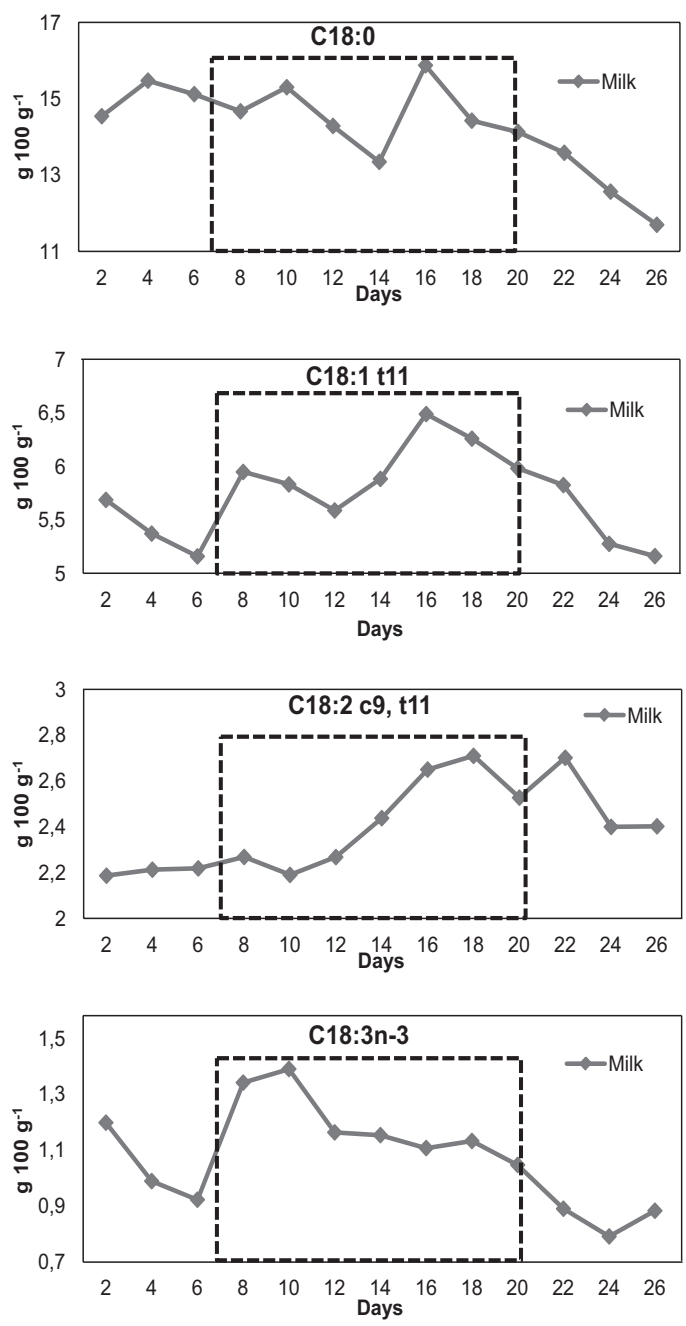

Figure 1. Temporal pattern $\left(\mathrm{g} 100 \mathrm{~g}^{-1}\right)$ of C18:0, C18:1 t11, C18:2 c9, t11 and C18:3n-3 of milk fat from ewes receiving a diet supplemented (days 7 to 20; broken lines) with extruded linseed.

et al., 2009; 60 days and Mele et al., 2011; 10 weeks). Mele et al. (2007) have shown that when feeding 30\% DM extruded linseed, the CLA contents reached their highest concentration after 4 weeks of supplementation, whereas n-3 FA reached its maximum content after 7 weeks of feeding. Therefore, the long-term lipid supplementation of extruded linseed is required to test the persistency of the level of obtained RA. It is known that dairy ewes grazing on pasture in the vegetative phase (Nudda et al., 2005) can enhance the RA content in ewe's milk; however, the feeding strategy used in this trial could be 
adopted when pasture is not readily available for dairy ewes to achieve a constant level of RA enrichment in milk fat.

Overall, the supplementation $\left(500 \mathrm{~g} \mathrm{ewe}^{-1}\right.$ milking $^{-1}$ ) of extruded linseed in ewes under grazing conditions did not have detrimental effects on the milk and cheese FA profile. The effect of extruded linseed supplementation in ewes under the same conditions with longer experimental periods and a more suitable statistical design must be investigated.

\section{Acknowledgements}

This trial was supported by a research grant from FIA PYT-2008-0213 (Fondo de Innovación Agraria, Ministerio de Agricultura, Chile).

\section{Resumen}

E. Vargas-Bello-Pérez, R. R. Vera, C. Aguilar, R. Lira, I. Peña y F. A. Tello. 2014. Ovejas en El objetivo de este ensayo fue evaluar el efecto de suplementar extruido de linaza en el perfil de ácidos grasos de leche y queso de ovejas en pastoreo extensivo. Durante 26 días, un grupo de nueve ovejas lactantes (Latxa $\times$ Milchschaf $\times$ Corriedale) fueron manejadas en pastoreo extensivo y suplementadas durante cada ordeño manual ( 830 y 1800 h) con $50 \%$ maíz $+50 \%$ avena (500 g oveja $^{-1}$ ordeño $\left.{ }^{-1}\right)$ durante los primeros 6 días (control; TC), de los días 7 al 20 se suplementaron con $25 \%$ maíz $+25 \%$ avena $+50 \%$ extruido de linaza (500 g oveja ${ }^{-1}$ ordeño $\left.{ }^{-1}\right)$ (extruido de linaza; TEL), y finalmente, del día 21 al 26 las ovejas fueron alimentadas con TC. El contenido de ácidos grasos saturados en leche fue reducido $(3,6 \%)$ mientras que los ácido grasos monoinsaturados, polinsaturados y n-3 fueron incrementados (7, 10 y $25 \%)$ en aquellas ovejas alimentadas con TEL. Se observó una correlación de ácido ruménico con ácido vaccénico $\left(R^{2}=0,68\right)$ en leche de ovejas alimentadas con TEL. Los quesos elaborados de ovejas alimentadas con TEL, aumentaron su contenido de n-3 y ácidos grasos poliinsaturados (21 y $7 \%$ ). En conclusión, el suplementar ovejas en pastoreo extensivo con extruido de linaza puede ser una alternativa que puede resultar en la elaboración de quesos con un valor nutricional más saludable desde el punto de vista humano. Además resulta necesario investigar más sobre el uso del extruido de linaza bajo las mismas condiciones con periodos más largos de experimentación usando un diseño estadístico más apropiado.

Palabras clave: Ácidos grasos n-3, Extruido de linaza, leche, oveja, queso.

\section{References}

Abilleira, E., M. Collomb, H. Schlichtherle-Cerny, M. Virto, M. de Renobales, and L.J.R. Barron. 2009. Winter/spring changes in fatty acid composition of farmhouse Idiazabal cheese due to different flock management systems. Journal of Agricultural and Food Chemistry 57:4746-4753.

Akraim, F., M.C. Nicot, P. Weill, and F. Enjalbert. 2006. Effects of preconditioning and extrusion of linseed on the ruminal biohydrogenation of fatty acids. 1. In vivo studies. Animal Research 55:83-91.

AOAC, 1984. Official Methods of Analysis, 14th edition. Association of Official Analytical Chemist, Arlington, VA, USA.

AOAC, 2006. Official Methods of Analysis, 18th edition. Association of Official Agricultural Chemists, Gaithersburg, MD, USA.

Bianchi, L., A. Bolla, E. Budelli, A. Caroli, C. Casoli, M. Pauselli, and E. Duranti. 2004. Effect of udder health status and lactation phase on the 
characteristics of Sardinian ewe milk. Journal of Dairy Science 87:2401-2408.

Bouattour, M.A., R. Casals, E. Albanell, X. Such, and G. Caja. 2006. Milk fatty acid composition and dairy performances in Lacaune sheep fed whole linseed and linseed oil with reference to CLA. Journal of Animal Science 84:64-64.

Branciari, R., A. Valiani, M. Trabalza-Marinucci, D. Miraglia, D. Ranucci, G. Acuti, S. Esposto, and L. Mughetti. 2012. Consumer acceptability of ovine cheese from ewes fed extruded linseed-enriched diets. Small Ruminant Research 106:S43-S48.

Gomez-Cortes, P., A. Bach, P. Luna, M. Juarez, and M.A. de la Fuente. 2009. Effects of extruded linseed supplementation on n-3 fatty acids and conjugated linoleic acid in milk and cheese from ewes. Journal of Dairy Science 92:4122-4134.

Luna, P., A. Bach, M. Juarez, and M. A. de la Fuente. 2008. Influence of diets rich in flax seed and sunflower oil on the fatty acid composition of ewes' milk fat especially on the level of conjugated linoleic acid, n-3 and n-6 fatty acids. International Dairy Journal 18:99-107.

Luna, P., J. Fontecha, M. Juarez, and M.A. de la Fuente. 2005. Changes in the milk and cheese fat composition of ewes fed commercial supplements containing linseed with special reference to the CLA content and isomer composition. Lipids 40:445-454.

Manso, T., R. Bodas, C. Vieira, A.R. Mantecon, and T. Castro. 2011. Feeding vegetable oils to lactating ewes modifies the fatty acid profile of suckling lambs. Animal 5:1659-1667.

Mele, M., G. Contarini, L. Cercaci, A. Serra, A. Buccioni, M. Povolo, G. Conte, A. Funaro, S. Banni, G. Lercker, and P. Secchiari. 2011. Enrichment of Pecorino cheese with conjugated linoleic acid by feeding dairy ewes with extruded linseed: Effect on fatty acid and triglycerides composition and on oxidative stability. International Dairy Journal 21:365-372.

Mele, M., A. Serra, G. Conte, A. Pollicardo, M. Del Viva, and P. Secchiari. 2007. Whole extruded linseed in the diet of dairy ewes during early lactation: effect on the fatty acid composition of milk and cheese. Italian Journal of Animal Science 6:560-562.

Mel'uchova, B., J. Blasko, R. Kubinec, R. Gorova, J. Dubravska, M. Margetin, and L. Sojak. 2008.
Seasonal variations in fatty acid composition of pasture forage plants and CLA content in ewe milk fat. Small Ruminant Research 78:56-65.

Mughetti, L., F. Sinesio, G. Acuti, C. Antonini, E. Moneta, M. Peparaio, and M. Trabalza-Marinucci. 2012. Integration of extruded linseed into dairy sheep diets: Effects on milk composition and quality and sensorial properties of Pecorino cheese. Animal Feed Science and Technology 178:27-39.

Nudda, A., M. A. McGuire, G. Battacone, and G. Pulina. 2005. Seasonal variation in conjugated linoleic acid and vaccenic acid in milk fat of sheep and its transfer to cheese and ricotta. Journal of Dairy Science 88:1311-1319.

Park, Y. W., M. Juarez, M. Ramos, and G.F.W. Haenlein. 2007. Physico-chemical characteristics of goat and sheep milk. Small Ruminant Research 68:88-113.

Plourde, M., F. Destaillats, P.Y. Chouinard, and P. Angers. 2007. Conjugated alpha-linolenic acid isomers in bovine milk and muscle. Journal of Dairy Science 90:5269-5275.

Sutherland, W.J. 2006. Ecological Census Techniques. 2nd edition. Cambridge University Press, Cambridge pp 446.

Ulbricht, T. L. V., and D.A.T. Southgate. 1991. Coronary heart-disease -7 dietary factors. Lancet 338.985-992.

Van Soest, P.J., J.B. Robertson, and B.A. Lewis. 1991. Methods for dietary fiber, neutral detergent fiber, and nonstarch polysaccharides in relation to animal nutrition. Journal of Dairy Science 74:3583-3597.

Vargas-Bello-Pérez, E., and P.C. Garnsworthy. 2013. Trans fatty acids and their role in milk of dairy cows. Ciencia e Investigación Agraria 40:449-473.

Vargas-Bello-Pérez, E., R.R. Vera, C. Aguilar, R. Lira, and J. Fernández. 2013. Feeding olive cake to ewes improves fatty acid profile of milk and cheese. Animal Feed Science and Technology 184:94-99.

Zhang, R.H., A.F. Mustafa, and X. Zhao. 2006. Effects of feeding oilseeds rich in linoleic and linolenic fatty acids to lactating ewes on cheese yield and on fatty acid composition of milk and cheese. Animal Feed Science and Technology 127:220-233. 